\title{
The bioeconomy and the forestry sector: Changing markets and new opportunities
}

\author{
by Luc C. Duchesne ${ }^{1}$ and Suzanne Wetzel $^{2}$
}

The bioeconomy is expected to replace the current information economy and will depend heavily on the manufacturing and trade of bioproducts, which are all commodities generated by living organisms through the use of technology and biotechnology, as well as nontimber forest products. In Canada alone, markets for bioproducts are in excess of $\$ 100$ billion annually. The bioeconomy should impact most of Canada's economic sectors: energy and transportation, food and agro-food, pharmaceuticals, nutraceuticals, forestry, materials and manufacturing, waste management and a large variety of consumer goods. The bioeconomy holds promises to wean the Canadian economy from its dependence on fossil fuels as a primary source of energy as well as platform chemicals in materials and manufacturing, while meeting the Kyoto commitments on greenhouse gas reductions. Finally, the bioeconomy will reduce the environmental impact of economic growth by increasing the use of industrial and urban wastes and developing goods that are biodegradable.

Key words: NTFP, ecology, forest economics, biomass, energy, pharmaceuticals, forest policies, agroforestry

La bioéconomie est susceptible de remplacer l'économie actuelle de l'information et dépendra principalement de la production et du commerce des bioproduits, constitués de tous les produits de commodité générés par les êtres vivants au moyen des technologies et des biotechnologies, ainsi que les produits forestiers non-ligneux. Seulement au Canada, les marchés pour les bioproduits excèdent plus de 100 milliards \$ par an. La bioéconomie devrait avoir un impact sur la plupart des secteurs économiques du Canada: l'énergie et les transports, le secteur alimentaire et agro-alimentaire, le secteur pharmaceutique, le secteur nutracétique, la foresterie, le secteur manufacturier et des matériaux, la gestion des résidus et une grande proportion des biens de consommation. La bioéconomie pourrait permettre de dégager l'économie canadienne de sa dépendance aux combustibles fossiles en tant que source principale d'énergie ainsi que de produits chimiques de base pour les matériaux et la fabrication, tout en répondant aux engagements de Kyoto relatifs à la réduction des gaz à effet de serre. Finalement, la bioéconomie réduira l'impact environnemental de la croissance économique grâce à l'utilisation accrue des résidus industriels et urbains et à l'élaboration de produits biodégradables.

Mots-clés: PFNL, écologie, économie forestière, biomasse, énergie, produits pharmaceutiques, politiques forestières, agroforesterie

\section{Introduction}

The bioeconomy is expected to replace the current information economy within the next twenty-five years. It will be based on life sciences and will draw on biomass in novel ways by integrating processes and knowledge derived from biotechnology and manufacturing. It will produce goods and services for all sectors of the economy. The arrival of the bioeconomy should pave the way to an unprecedented expansion of the forestry sector by opening new markets and offering new perspectives on the way that forest resources will be managed. In short, we can expect demand for forest resources to increase, as they become favoured sources of energy, plastics, pharmaceuticals, nutraceuticals, foods and consumer products.

The commodities traded in support of the bioeconomy are termed bioproducts because they are derived from all types of living organisms: plants, animals, insects, viruses, fungi and bacteria. The list of materials and products that can be made from renewable biological resources instead of petrochemicals is impressive: fuels, adhesives, solvents, plastics, paints, fabrics, fertilizers, pesticides, lubricating oils, biodegradable packaging, composite construction materials, value-added wood products, pharmaceuticals, nutraceuticals, and a plethora of consumer products in all aspects of Canadian life.

In some ways, the bioproducts industry is as old as humankind. Throughout history, humanity has depended on

\footnotetext{
${ }^{1}$ Natural Resources Canada, Canadian Forestry Service, 1219 Queen S East, Sault Ste. Marie, Ontario P6A 2E5. E-mail: luduches@ NRCan.gc.ca ${ }^{2}$ Natural Resources Canada, Canadian Forestry Service, 1219 Queen St East, Sault Ste. Marie, Ontario P6A 2E5. E-mail: swetzel@ NRCan.gc.ca
}

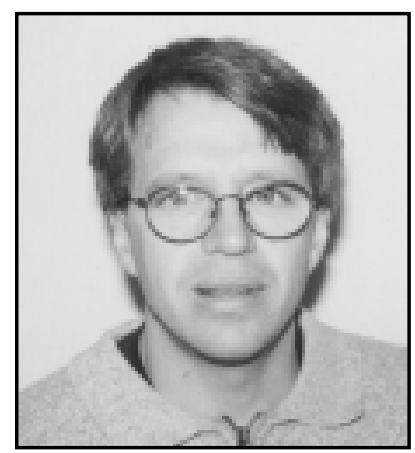

Luc C. Duchesne

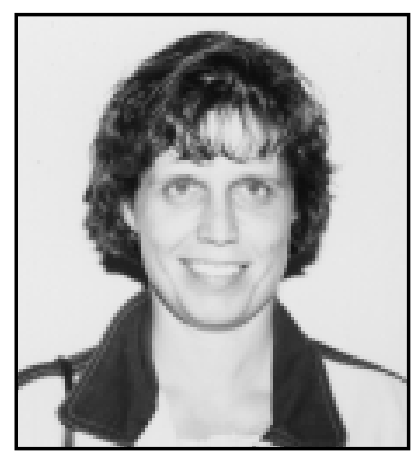

Suzanne Wetzel plants and animals for food, shelter, medicines, tools and clothing. However, the bioproducts industry is now made possible by new knowledge and processes in the fields of chemistry, wood processing, pharmacology and biotechnology. As well, market globalization and the need to gradually phase out the use of fossil fuels create economic incentives that are favourable to the bioproducts industry in such varied fields of application as medical sciences, energy, housing, transportation, food sciences, cosmetics, manufacturing processes and many other aspects of everyday life.

The bioeconomy represents the latest of the economic cycles that have marked humankind (Davis and Meyer 2001). Through the Palaeolithic era hunting-and-gathering economies ruled for hundreds of thousands of years before they were replaced by agrarian economies, which dominated for 10000 years. Next, the industrial economies took over across the western world 
and displayed several cycles of their own. The first industrial economy began in Britain in the 1760s. In the United States, the industrial economy started to unwind in the 1950s and is being replaced by the information economy. But the information technology is expected to last for 75 years, ending in the late 2020s. Then the bioeconomy will rule supreme for an undetermined period of time. However, it is expected to have profound effects on society and culture.

As far as the forestry sector is concerned, the bioeconomy will take shape in two forms. On the one hand, there should be a diversification of biological products managed from forest ecosystems such as non-timber forest products (NTFP) (Duchesne et al. 2000, Duchesne and Wetzel 2002, Gautham and Watanabe 2002). In recent years, NTFP have received a great deal of attention as tools to diversify rural, northern and First Nation economies, generate sustainable forest communities and subsidize forest operations (Duchesne and Wetzel 2002).

On the other hand, there should be increased application of biotechnology in biomass processing, which will yield new markets and improve the economic and environmental efficacies of current industrial applications. Plant biomass can be processed and converted by fermentation and other processes into chemicals, fuels and materials that are collectively termed bioproducts. In the end, there is not much difference between NTFP and bioproducts. Therefore, for the purpose of this manuscript the term "bioproducts" refers to both NTFP (Duchesne et al. 2000) and the biotechnologically derived bioproducts (OECD 2001). The objective of this manuscript is to present an overview of the potential for the bioproducts industry to the Canadian forest sector.

\section{Biotechnology and the Bioeconomy}

Biotechnology extends far beyond the creation of genetically modified organisms. In reality, biotechnology provides tools for adapting and modifying the biological organisms, products, processes and systems found in nature to develop new processes that are eco-efficient and products that are not only more profitable but also more environment-friendly. It is also providing an increasing range of tools for the industry to continue improving cost and environmental performance beyond what could normally be achieved using conventional chemical technologies (OECD 2001). Enzymes extracted from naturally occurring microorganisms, plants and animals can be used biologically to catalyze chemical reactions with high efficiency and specificity. Compared to conventional chemical processes, biocatalytic processes usually consume less energy, produce less waste and use less organic solvents, which translate into lower production and environmental costs. Moreover, by imitating natural selection and evolution, the performance of naturally occurring enzymes can be improved. Enzymes can rapidly be "evolved" through mutation or genetic engineering and selected using high-throughput screening to catalyze specific chemical reactions and to optimize their performance under certain industrial conditions.

Microorganisms can also be modified favourably by genetic engineering. With targeted technology it is possible to turn each cell into a highly efficient "mini reactor" that produces in one step and at high yield what would take an organic chemist a number of steps with much lower yield. This technique is called "metabolic engineering."
Biotechnology can also help us in devising a new approach called "industrial ecology." With industrial ecology, waste heat, waste biomass and food are passed from one industry sector to the next in a manner that emulates food chains. Hence, groups of companies can mimic the co-operative action of organisms in natural ecosystems by clustering around the processing of a feedstock such as biomass so that the by-product of one is the starting material for another.

\section{The Global Bioeconomy}

The depletion of fossil fuels [proven reserves of oil, coal and natural gas will be depleted in 41, 22.5 and 63 years, respectively (BP Amoco 2000)], the decline in production of fossil fuels and an increase in demand by developing economies will likely generate a further increase in the cost of oil on the world market (Ulgiati 2001). This will continue to affect Canada's economy, as it is largely dependent on fossil fuels for transportation, electricity, heating and manufacturing. As such, it provides an economic incentive for research and development toward the creation of a competitive bioproducts industry that will become a reliable and sustainable source of energy and manufacturing goods. However, it is a matter of debate whether shifting from fossil fuels to renewable fuels will result in a slowdown in economic growth, or whether it will propel the Canadian economy forward seamlessly (Ulgiati 2001). Hence, it is critical to initiate research and development aggressively in this field.

It is predicted that by 2010 biotechnology will affect $20 \%$ of the world chemical market, which will translate into roughly US \$280 billion annually. Consequently, foreign governments have already taken steps to foster domestic bioeconomies. The Organisation for Economic Co-operation and Development is a thirty-two-member organization dedicated to sustainable economic development and envisions biotechnology as a cornerstone of the bioeconomy (OECD 2001). As well, OECD members are pursuing individual strategies that are suited to their resources and knowledge. In Scandinavia for instance, governments are promoting the use of fastgrowing trees such as poplar, willow and aspen to make paper products and composite construction materials. The United States is working towards tripling its use of bio-based products and energy by 2020 (English and Ewing 2002). To reach that goal, the federal government has issued a 30-point plan, which includes incentives to help industry create and adopt the technologies needed to make bioproducts and energy cost-competitive with fossil fuels and petrochemicals, as well as policy actions, such as tax incentives, that support the industry. In addition, the US government will increase its purchases of bio-based energy to $3 \%$, and of bio-based products to $8.2 \%$ of total energy consumption by 2020 (English and Ewing 2002).

\section{Bioeconomy in Canada}

Together the markets of gasoline, heating oil, plastics, natural food products and pharmaceuticals are worth in excess of $\$ 100$ billion in Canada. These are important economic sectors, which explains why there is increasing interest by the private sector and governments in promoting a bioeconomy based on the use of biomass such as agricultural crops, mill waste and fast-growing trees, instead of fossil fuels. Such a biobased economy builds on Canada's natural strengths and traditional industries-agriculture, forestry and biotechnolo- 
gy-while holding out the promise of a cleaner environment, increased energy security and prosperity with added socioeconomic advantages to rural communities.

The bioproducts industry could assist Canadian society at large in meeting the environmental commitments associated with the Kyoto protocol. Indeed, there is fear that sustaining Canada's economic growth may outstrip the incremental gains in environmental and sustainable performance. By ratifying the Kyoto protocol on greenhouse gas emissions, this country is recognizing the need to create a new type of economy that integrates environmental costs as part of doing business. This new economy should rely heavily on the bioproducts industry as a source of ecologically sound fuels. As well, an added advantage of the bioeconomy is that the use of green fuels will lower the risk of oil spills in the ocean, inland waterways and highways. As well, an economy based on products that are biodegradable and recyclable will reduce the production of toxic wastes and their subsequent environmental and health damage.

The bioeconomy holds the promise of economic renewal in many areas of Canada where natural resources have failed to generate sustainable employment. As well, the new bioeconomy is critical to resolve the economic and social problems associated with the so-called brain drain. We have to provide our highly trained personnel with opportunities to secure challenging employment in Canada. The bioproducts industry will need such people. Interestingly, because emphasis is to create opportunities for rural, northern, fishing and First Nation communities, the bioproducts industry is expected to reverse the urban exodus. This is a critical issue in those communities where there is a need to maintain lifestyle and cultural traditions, by offering people the alternative to stay in their hometown.

In Canada, governments, industries and universities involved in the research, development and production of bio-fuels and products want to keep pace for many reasons, one of which is the prospect of a cleaner environment. Indeed, the potential benefits of the bioproducts industry represent opportunities for several billion dollars in revenues, job creation, environmental conservation, and economic growth. Its emergence is a tribute to the ingenuity of Canadians as it reshapes many industrial sectors to meet the new market demands by drawing on long-established expertise, industries, markets and culture. In agriculture alone, it is thought that the bioeconomy will contribute an additional $\$ 70$ billion in goods, which will undoubtedly benefit rural economies.

Canada's forestry sector is expected to contribute to, and benefit greatly from, Canada's bioeconomy. Although there has been a great deal of research conducted in various disciplines connected with forest biomass and energy from forests (Hall 2002), forest biotechnology (Charest and Duchesne 1995), and NTFPs (Duchesne and Wetzel 2002), there is an urgent need to paint a broad picture of the potential of the bioproducts industry in the bioeconomy. Particularly, the emergence of economic strategies to generate fuel from wood waste will be a determinant factor in the forest industry (DynaMotive 2003).

\section{Canadians and the Bioeconomy}

Public opinion will be a critical component of the bioeconomy. Canadians are expected to invest in the bioeconomy either as taxpayers, shareholders of publicly trading companies, entrepreneurs and consumers. Therefore, the opinion and endorsement of Canadians is a critical issue.

Pollution Probe (Hansen 2003) conducted a survey of the attitude of Canadians surveyed with regard to the bioeconomy. In short, the survey showed that Canadians are willing to embrace this new industry and envision that governments should play a critical role in its development. However, there are a number of concerns as outlined below:

Genetically Modified Organisms: Respondents were generally receptive to the idea of a bio-based economy that included the usual protections for the environment provided by civil society. They were divided over the issue of genetically modified organisms, specifically whether or not they could or needed to be contained. And if it was possible to contain genetically modified organisms, how long was long enough? When would Canadians know whether the level of risk was acceptable and manageable, or too great to permit genetically modified organisms to grow outdoors, if at all?

The Role of Governments: Almost all respondents stated that governments have a role to play, especially in the early days of a bio-based economy. What the primary role was-protector or promoter- depended on who was talking. Some said the governments should promote the bio-based economy by providing tax breaks. Others said the governments should play the protector by, for instance, regulating the use of genetically modified organisms and establishing policy frameworks. One respondent said governments could play both roles provided they worked within an overarching policy framework.

Policy Framework: Canada and Canadians need a policy framework that will reflect the benefits and drawbacks of a bio-based economy, as well as explain and order the roles of governments. Such a policy framework would set out the governments' priorities and give Canadians a big picture analysis so they could make informed choices and decisions about the new economy and bio-based industries.

Communications: Almost everyone interviewed saw the need for communications and thought the governments should either lead or take a major role. Some said governments should promote a bio-based economy here and abroad. Others said governments should organize public consultations for all the stakeholders to explain in an honest way the technologies, ethics, benefits and costs of bio-based industries, and to distinguish between the technologies that include genetically modified organisms and those that do not. Furthermore, one respondent said a multi-stakeholder group would have to prepare the educational materials for public consultations because no sector-government, industry, research or environmental-had the trust of the general public.

Research and Development, Including Commercial Development: The issue for non-government organizations is the imbalance of existing research. Right now, governments and industry are investing money in researching the technology required for a bio-based economy, but are not adequately researching the environmental protections needed in such an economy, especially when the processes and products involve genetically modified organisms.

The Benefits of a Bio-Based Economy: There were concerns about the lack of a policy framework for land use in rural Canada. What happens when one industry moves into an area and buys up the land to grow crops needed as feedstock? Rural Cana- 
da could end up with a number of one-industry towns based on, for example, the production of bio-based fuels from corn, which in time and for much the same reasons could share the fate of similar communities based on mining or forestry. There are other related questions that follow when land is used to grow crops for industry.

Biodiversity Conservation: What happens to biodiversity when thousands of hectares are devoted to a single crop? There is a large body of knowledge on the impact of forestry operations on biodiversity. Landscape ecologists and wildlife biologists have addressed the issue of landscape fragmentation for a number of years. However, adding biomass harvesting to traditional forest harvesting, as well as harvesting hitherto non-productive forests, will elicit new research questions with regard to biodiversity conservation and ecological functioning.

Soil Conservation: Will the soil deteriorate because some bioproducts use the parts of the plant or trees once left behind to decompose and nourish the soil? This is a critical issue that needs to be supported by ecological impact research in order to predict, minimize and alleviate the problems associated with intensive vegetation management.

Social sustainability: Will local communities suffer when tracts of land are planted with fast-growing trees, such as aspen, willow and poplar, which draw more water from aquifers and groundwater than slower-growing trees? Water is an issue that may become increasingly important under climate change. However, communities may also benefit a great deal from the bioeconomy.

\section{Forest Bioproducts in the Bioeconomy}

The forest product industry has been a key contributor to Canada's wealth and prosperity as a result of over 135 years of success in the global marketplace (Agriculture and AgriFood Canada 2002). The industry exports over 250 products to over 175 countries. Canada's forestry sector is a major contributor to the economy, with $2.9 \%$ of the gross domestic product as well as 353000 direct full time jobs. In 2001 it contributed to a positive trade balance of $\$ 34$ billion (Natural Resources Canada 2002.). However, the global trade of forest products, mainly lumber and paper products, is changing rapidly under the influence of international competition, overcapacity, tariffs and a shift in consumer demand for green products. The maintenance and growth of market share faces a climate of ever-tighter margins where mechanization will become an even greater necessity for competitiveness. In order to maintain a positive trade balance in the long term, it is imperative that Canada not only join other countries in systematically pursuing new value-added uses for forest products and by-products, but also seize the opportunity presented by its abundant forest resources to lead the world in research and development of an industry based on bioproducts.

The development of the forest industry has seen the integration of various manufacturing initiatives to reduce wastes and recover energy from wood processing operations. Indeed, the widespread use of waste wood from sawmilling operations by the pulp and paper industry has been a critical issue in the greening of the logging industry since the 1970s and has been met with a great deal of enthusiasm. However, the bioproducts industry is now demanding that we should be able to create further linkages with other industries both to address market needs as well as to better use resources from the forests.
As employment for the bioproducts industry will vary from small to large industrial complexes, this industry addresses the needs for supporting local economies. Conducting research on value-added products, which are essential for local economies, can further enhance this.

Another problem of rural economies is that private landowners, who hold $5 \%$ of Canada's forests, often struggle to generate revenues from the land, which is often exacerbated by the need to preserve landscape values and exclude forest harvesting. The industrialization of agriculture, as well as the urban exodus, has created a largely unused forest resource on these private lands. However, the bioproducts industry offers opportunities to generate revenues, either through casual harvest or intensive management of biocommodities.

There is a need to redress the economic downfall associated with lumber tariffs, mechanization of the forest industry and poverty in rural, northern, and First Nation communities. Because the economy of these communities is often highly dependent on the forest industry, it is critical to diversify these economies to increase the economic stability of such areas. Recent trends show that international competition requires that forest operations should mechanize in order to create profit margins acceptable to investors. The downside of this, clearly, is that the mechanization of forest operations is reducing employment, which is a critical issue to these rural, forest and First Nation communities.

However, markets are changing and opening new windows of opportunity for the forest industry, which create new challenges to innovation. The two biggest industrial products are fuels and plastics, which are the very centre of the Canadian economy and reflect the gradual shift from fossil fuel consumption to green energy and material sources. Canada has the capacity to derive at least $5 \%$ of its transportation fuel and $10 \%$ of its organic chemicals and plastics from biomass by 2010 and to double that by 2020. If the government were to implement policy to set targets of production at $5 \%$ transportation fuels and $10 \%$ organic chemicals from biomass, we could stimulate investments of $\$ 3-5$ billion and create 6000-10 000 new direct jobs in just under seven years (Agriculture and Agri-food Canada 2002).

There is an international demand for bioplastics. The European Union is committed to the creation of cars that are made of recyclable components. This opens the door to the creation of new commodities in forestry. Particularly, it may create business opportunities from waste products generated by forest operations and processing. We need to create new linkages and coordination between different industrial sectors that would either compete or work independently of each other. Traditionally, the forestry sector has acted independently of other sectors. However, there is evidence that cross-sector development would be beneficial to all concerned. For this, however, we have to understand that the integrated management of forest resources can lead to enhanced benefits to all sectors.

First Nations require increased participation in Canada's forestry sector through land claims, implementation of treaty rights, forest management licenses, as well as reserve management. The bioproducts industry offers many opportunities for First Nation communities by promoting products that are often consistent with traditional lifestyles and values. This is particularly well adapted to past efforts to create sustainable and culturally meaningful employment in First Nation communities. This is especially important in view of the growing recogni- 
tion of traditional ecological knowledge as a source of knowledge. At the international level, the UN Convention on Biological Diversity, Article 8(j) addresses the respect, preservation and maintenance of knowledge, innovations, and practices of indigenous and local communities relevant for the conservation and sustainable use of biological diversity, and indicates that signatory states "shall, as far as possible and as appropriate, encourage the equitable sharing of the benefits arising from the utilization of such knowledge, innovations and practices." United Nations Council Economic Development Agenda 21 calls for signatory countries to "develop national forest plans for sustainable development and to recognize the multiple role of forests including biodiversity."

The Canadian forestry sector has an excellent reputation for research and development with the support of a large network of federal and provincial facilities and universities. This network is linked by a number of key nodes across the country. The industry R\&D investment was $\$ 350$ million in 2000 , which is less than half of the R\&D investment in the United States and less than a third of the R\&D investment in Scandinavia. Much of this research is highly pertinent to the bioproducts industrial sector and is critical from an environmental, social and economic perspective in order to maintain Canada's prosperity. Indeed, the bioproducts industry offers us the possibility to meet the demands of the domestic and international markets for such products as clean energy, consumer goods that are derived in an environmentally safe way, foods that are wholesome and affordable, new medicines that are inexpensive and effective, and many others.

\section{Conclusion}

The bioeconomy is coming. There is no doubt. It may arrive progressively and be driven by emerging economic opportunities, political constraints and environmental necessities. It may come quickly in response to global political conflicts and economic pressures. Regardless, its emergence will change the way Canadians live; that too is certain. Pundits predict its impact on the Canadian economy and culture may be as profound as that of information technology.

The pace at which the bioeconomy will evolve, together with its impact on society, will depend largely on the way that governments, the industrial sector and the general public plan and organize themselves within this new economy. Scientists and governments have a responsibility to address three fundamental questions about the bioeconomy: Will shifting from an economy dependent on fossil fuels to a bio-based economy result in an economic slowdown? Will the environment improve under the bioeconomy? Will the standard of living of all Canadians be improved by the bioeconomy?

A more bio-based economy offers hope both for developed and developing countries. For developed countries, it presents the opportunity to use their technological capabilities for national security of energy and chemical supply. For developing countries, it provides the potential at least partially to leapfrog the age of fossil fuels and petrochemicals to the age of more environment-friendly biofuels and biochemicals that can be produced locally, improving the economy and quality of life.
Recently, the release of the new National Forest Strategy (http://nfsc.forest.ca) has paved the way for the broad acceptance of the bioproducts industry. Indeed, seven of the eight goals (Ecosystem-based management, Sustainable forest communities, Rights and participation of aboriginal people, Forest products benefits, Knowledge and innovation for competitiveness and sustainability, Urban forests and public engagement in sustainability, and Private woodlots' contribution to sustainability) are highly pertinent to the bioproducts sector.

Among the Canadian industrial sectors, the forest industry is the most technologically advanced. However, it is important to emphasize that the bioproducts field covers a broad range of activities with various technological levels. At one end of the spectrum, the industry depends heavily on technological inroads. At the other end of the spectrum, there are many lowtech products that are harvested and transformed by small entrepreneurs. Collectively, these products contribute greatly to rural economies and should play a greater role in the future, as the bioproducts sector expands. As such, the bioproducts industry will need to be supported by economic incentives and policies that are relevant to the entire spectrum of the industry.

\section{References}

Agriculture and Agri-Food Canada. 2002. Non-Food/Non-Feed Industrial Uses for Agricultural Products . Horticulture and Special Crops Division, Agriculture Industry Services Directorate, Market and Industry Services Branch, Agriculture and Agri-Food Canada. Ottawa, ON. 88 p.

BP Amoco 2000. Statistical Review of the World Energy .

Charest, P.J. and Duchesne, L.C. 1995. Recent progress in forest biotechnology in Canada. Canadian Forestry Service, Petawawa National Forestry Institute. PI-X-120.

Davis, S. and C. Meyer. 2001. Visions of the $21^{\text {st }}$ Century. What will replace the Tech Economy? www.time.com. /time/reports/v21/work/ mag_tech.hmtl.

Duchesne, L.C. and S. Wetzel. 2002. Managing timber and non-timber forest product resources in Canada's forests: Needs for integration and research. The Forestry Chronicle 78: 837-842.

Duchesne, L.C., J. C. Zasada and I. Davidson-Hunt. 2000. Nontimber forest product industry in Canada: Scope and research needs. The Forestry Chronicle 76: 743-746.

DynaMotive. 2003. Green fuels to the world. www.dynamotive.com English, G. and T.W. Ewing 2002. Vision for the bioenergy and biobased products in the United States. Biomass Technical Advisory Committee. www.bioproducts-bioenergy.gov

Gautham, K.H. and T. Watanabe. 2002. Silviculture for non-timber forest products management: challenges and opportunities for sustainable forest management. The Forestry Chronicle 78: 830-832.

Hall, J.P. 2002. Sustainable production of forest biomass for energy. The Forestry Chronicle 78: 391-396.

Hansen, J. 2003. Challenge Paper on the Biobased Economy. Pollution Probe (In press).

Natural Resources Canada. 2002. Important facts on Canada's natural resources. http://www.nrcan.gc.ca/statistics/

OECD. 2001. The application of biotechnology to industrial sustainability - a primer. Organization for Economic Development and Cooperation. Paris Cedex 16, France.

Ulgiati, S. 2001. A comprehensive energy and economic assessment of biofuels: When "green" is not enough. Critical Rev. Plant Sci. 20: 71-106. 